\section{UJMM

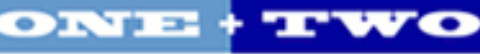

Volume 6 | 2016 Spring 2016

\section{Undergraduate Journal of Mathematical} Modeling: One + Two

2016

\title{
Electrical Efficiency of a Solar Cell
}

Johnnie Cairns

University of South Florida

\author{
Advisors: \\ Arcadii Grinshpan, Mathematics and Statistics \\ Scott Campbell, Chemical and Biomedical Engineering \\ Problem Suggested By: Scott Campbell
}

Follow this and additional works at: https://digitalcommons.usf.edu/ujmm

Part of the Mathematics Commons

UJMM is an open access journal, free to authors and readers, and relies on your support: Donate Now

\section{Recommended Citation}

Cairns, Johnnie (2016) "Electrical Efficiency of a Solar Cell," Undergraduate Journal of Mathematical Modeling: One + Two: Vol. 6: Iss. 2, Article 1.

Available at: https://digitalcommons.usf.edu/ujmm/vol6/iss2/1 


\title{
Electrical Efficiency of a Solar Cell
}

\begin{abstract}
Our goal was to determine the electrical efficiency of a solar cell, specifically a CulnGaSe2 solar cell. Solar cells work by converting energy from the sun in the form of photons to electrical energy in the form of electrons. However, the solar energy converted into electrical energy is limited by a property of solar cells called the quantum efficiency. The quantum efficiency of a solar cell is the fraction of photons hitting the cell that are converted into electrons; quantum efficiency varies as a function of wavelength. Another key component which also varies as a function of wavelength is spectral irradiance, i.e. the power per square meter of a photon. The electrical efficiency of a solar cell is the ratio of the energy produced by the cell over the energy that would be produced if the cell absorbed all of the energy in each photon. To determine this ratio, data from a spreadsheet providing the spectral irradiance for solar radiation reaching the Earth's surface was used to find the energy a cell would produce if it absorbed all of the sun's energy. This data was then combined with the cell's unique quantum efficiency data to determine the energy that the solar cell would actually produce which was then used to determine the electrical efficiency.
\end{abstract}

\section{Keywords}

solar, energy, efficiency

\section{Creative Commons License}

\section{cc) (i) $\ominus$}

This work is licensed under a Creative Commons Attribution-Noncommercial-Share Alike 4.0 License. 


\section{PROBLEM STATEMENT}

A solar cell collects solar energy in the form of photons and converts the solar energy into electrical energy. The energy of the photons varies with wavelength of light though and the different wavelengths have different intensities. This makes the calculation of efficiency for a solar cell non-trivial. The quantum efficiency $\eta$ of a solar cell is the fraction of incident photons that are converted into electrons by the cell and it is also a function of wavelength. The electrical efficiency of a solar cell is the ratio of the current produced by the cell over the current that would be produced if every photon generated an electron for electrical current. It may be calculated from:

$$
\text { Electrical efficiency }=\frac{\int \eta \mathrm{P} \lambda \mathrm{d} \lambda}{\int \mathrm{P} \lambda \mathrm{d} \lambda}
$$

where $P$ is the spectral irradiance in $\mathrm{W} / \mathrm{m}^{2} \cdot \mathrm{nm}, \lambda$ is the wavelength in $\mathrm{nm}$ and $\eta$ is the quantum efficiency. A data file will be provided that contains $\mathrm{P}$ as a function of $\lambda$ for solar radiation reaching the Earth's surface. A recently developed $\mathrm{CuInGaS}_{2}$ solar cell has the following quantum efficiencies (as a function of wavelength):

\begin{tabular}{|c|c|c|c|}
\hline Wavelength, $\lambda(\mathrm{nm})$ & Quantum Efficiency, $\eta$ & Wavelength, $\lambda(\mathrm{nm})$ & Quantum Efficiency, $\eta$ \\
\hline 300 & 0.00 & 750 & 0.53 \\
350 & 0.08 & 800 & 0.50 \\
400 & 0.44 & 850 & 0.48 \\
450 & 0.59 & 900 & 0.38 \\
500 & 0.70 & 950 & 0.30 \\
550 & 0.68 & 1000 & 0.16 \\
600 & 0.64 & 1050 & 0.02 \\
650 & 0.63 & 1100 & 0.00 \\
700 & 0.63 & & \\
\hline
\end{tabular}

Table 1: Quantum efficiencies of the $\mathrm{CuInGaS}_{2}$ solar cell being studied.

The quantum efficiency is zero for all wavelengths less than $300 \mathrm{~nm}$ and all wavelengths greater than $1100 \mathrm{~nm}$. We will determine the electrical efficiency of this solar cell. 


\section{MOTIVATION}

Some of the common sources of energy in the world today come from the following: fossil fuels, wind turbines, hydroelectric systems, nuclear power plants, and solar cells. Fossil fuels and solar cells receive their energy exclusively from the sun, which is one of the most reliable sources of energy we have on Earth as it will be around for as long as there is life on Earth. Fossil fuels are essentially just molecules which have stored up the sun's energy over a very long period of time. However, unlike solar cells, fossil fuels are very harmful to the environment. The environmental impacts of fossil fuels such as natural gas and coal are very well known to the general population in this day and age. The energy in fossil fuels is captured mainly through combustion reactions which yield carbon dioxide $\left(\mathrm{CO}_{2}\right)$ as a product. Carbon dioxide plays a large role in preventing heat that enters Earth's atmosphere from reflecting back into space, thus creating higher temperatures on Earth. While there is a need for some carbon dioxide in the atmosphere to keep our planet at a habitable temperature, there is not a need for the excessive amounts of $\mathrm{CO}_{2}$ that the human race has produced in the past 100 years or so. This overproduction of carbon dioxide is a very serious problem and it alone is a good enough reason to encourage a change in the realm of energy production in which other energy sources such as solar, wind, and water-based systems become much more prevalent.

Having explained why there is a need for new sources of energy such as solar cells, one might be wondering why they are not more commonly used at the moment. The answer lies mainly in the fact that energy sources such as solar cells are relatively new and are thus often more expensive than simply using fossil fuels. In order to create a more widespread use of energy methods such as solar cells, scientists and engineers need to create cheaper solar cells. Following this thought, in order to create cheaper solar cells, they must create solar cells with 
higher electrical efficiencies so that the cells are capturing the maximum amount of energy from the sun as possible.

The objective of this project was to determine the electrical efficiency of a recently developed $\mathrm{CuInGaS}_{2}$ solar cell.

\section{MATHEMATICAL DESCRIPTION AND SOLUTION APPROACH}

The central mathematical equation to this project was the equation for the electrical efficiency of a solar cell, as follows:

$$
\text { Electrical efficiency }=\frac{\int \eta \mathrm{P} \lambda \mathrm{d} \lambda}{\int \mathrm{P} \lambda \mathrm{d} \lambda}
$$

While there is an equation that can be used to solve for $\mathrm{P}$, spectral irradiance, it is very complex and involves a variable, photon flux $(\Phi)$, which was not given in this problem. This being said, directly calculating the integral of either the numerator or the denominator of the electrical efficiency equation is impossible. However, it is possible to calculate an approximate value for each integral using trapezoidal Riemann sums which is very close to the actual value if the interval of wavelength being used is sufficiently small. In order to calculate these Riemann sums, data showing the spectral irradiance, $\mathrm{P}$, of solar radiation reaching the Earth's surface needs to be, and is provided. The spectral irradiance data was provided for wavelengths between $280 \mathrm{~nm}$ and $4000 \mathrm{~nm}$, and the data's intervals were always less than $5 \mathrm{~nm}$. A portion of this data can be seen in Table 2 of the appendices. 


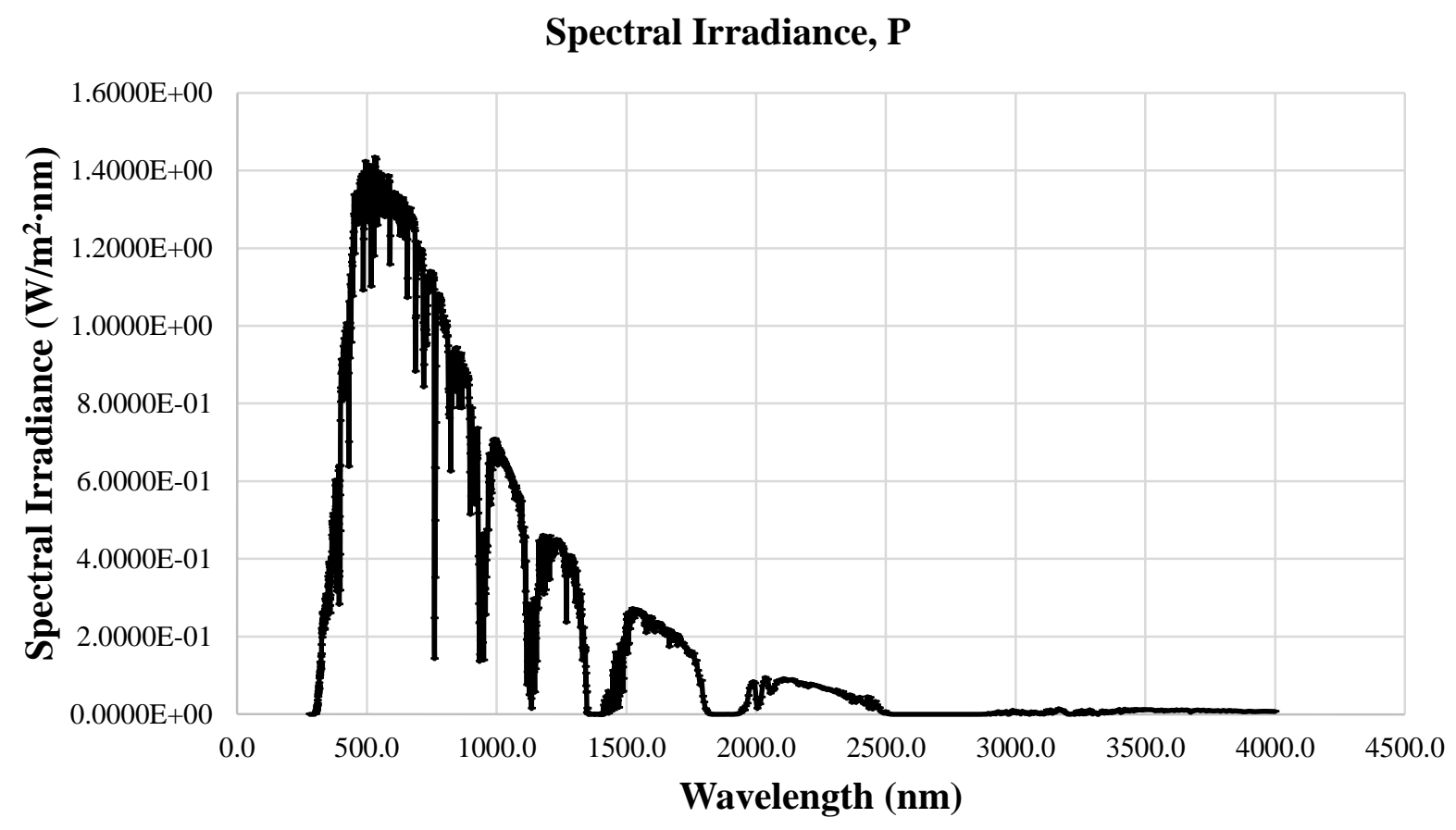

Figure 1: Graph presenting spectral irradiance data provided as a function of wavelength.

Thus, with this data the best possible approximation would be made using Riemann sums with intervals of $5 \mathrm{~nm}$. The general format of the Riemann sums would then be as follows:

$$
\sum_{i=1}^{n} \frac{f\left(x_{i-1}\right)+f\left(x_{i}\right)}{2} \Delta x=5\left(\frac{f\left(x_{0}\right)}{2}+f\left(x_{1}\right)+f\left(x_{2}\right)+\cdots+f\left(x_{n-1}\right)+\frac{f\left(x_{n}\right)}{2}\right)
$$

where $\Delta x$ is equal to the width of each trapezoid, $5 \mathrm{~nm}$, and $f(x)$ is equal to $P \cdot \lambda$ when approximating the integral corresponding to the denominator of equation (1) while $f(x)$ is equal to $\eta \cdot P \cdot \lambda$ when approximating the integral corresponding the numerator. The function $f(x)$ is also equal to the height of one side of each individual trapezoid.

Although the provided data gave spectral irradiance, $\mathrm{P}$, in intervals no greater than $5 \mathrm{~nm}$, the values for quantum efficiency, $\eta$, were spaced out in intervals of $50 \mathrm{~nm}$ from $300 \mathrm{~nm}$ to 1100 $\mathrm{nm}$. In order to find what the values of quantum efficiency were at all of the wavelengths were 
not given in the data, Excel was used to produce a line that fitted the data's curve. The line used to fit the curve was a polynomial of the sixth degree and was as follows:

$$
\begin{aligned}
\eta(\lambda)=4 \times 10^{-14} \lambda^{6}-2 \times 10^{-10} \lambda^{5}+3 \times 10^{-7} \lambda^{4}-3 \times 10^{-4} \lambda^{3}+0.1152 \lambda^{2} \\
-26.338 \lambda+2326.3
\end{aligned}
$$

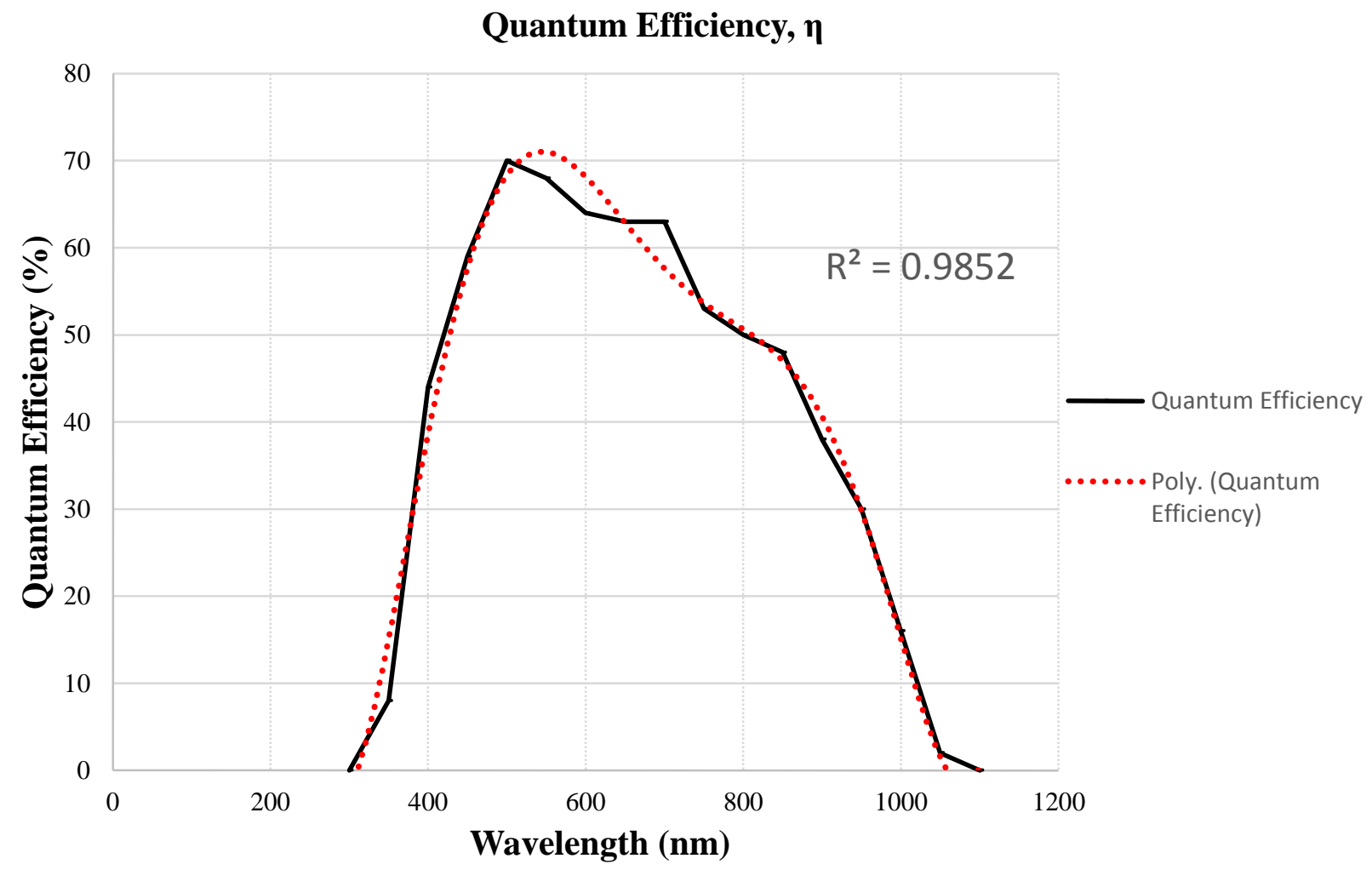

Figure 2: Graph showing line of best fit and $\mathrm{R}^{2}$-value for quantum efficiency curve.

This line fit to the curve had an $\mathrm{R}^{2}$ value of $\mathrm{R}^{2}=0.9852$. This is a value very close to 1 and therefore shows that this line is able to accurately describe values of quantum efficiency as a function of wavelength. Combining this new data for quantum efficiency with the data for spectral irradiance it was then possible to find all of the corresponding values of $f(x)$ in the Riemann sums of equation (2) which would be used to approximate the integrals in equation (1), thus allowing us to solve for the electrical efficiency of the solar cell. 
After using equations in Excel to multiply spectral irradiance, $\mathrm{P}$, by wavelength, $\lambda$, the Riemann sum was calculated using Excel's "SUM" function to find the denominator in equation (1):

$$
\int_{280}^{4000} P \lambda d \lambda
$$

Then, Excel was used to multiply the values for spectral irradiance, $\mathrm{P}$, and wavelength, $\lambda$, by the values for the quantum efficiency, $\eta$, of the solar cell. This data was then also added together in intervals of 5 , divided by 2 , and multiplied by $5 \mathrm{~nm}$ as corresponding to the Riemann sum in equation (2) in order to give an approximation for the numerator of equation (1):

$$
\int_{300}^{1100} \eta P \lambda d \lambda
$$

The interval of integration for this part of the problem was restricted to the range of $300 \mathrm{~nm}$ to $1100 \mathrm{~nm}$ due to the fact that the quantum efficiency was zero for all wavelengths outside of this range.

With all of this information in hand, it was easily possible to finally determine the electrical efficiency of the $\mathrm{CuInGaSe} \mathrm{I}_{2}$ solar cell. Combining the results from equations (4) and (5), the mathematics was as follows:

$$
\text { Electrical efficiency }=\frac{\int \eta P \lambda d \lambda}{\int P \lambda d \lambda}=\frac{\int_{300}^{1100} \eta P \lambda d \lambda}{\int_{280}^{4000} P \lambda d \lambda} \approx \frac{2.2904 \times 10^{5}}{7.9258 \times 10^{5}}=0.28898
$$

Also, here is a visual representation of the result in equation (6). 


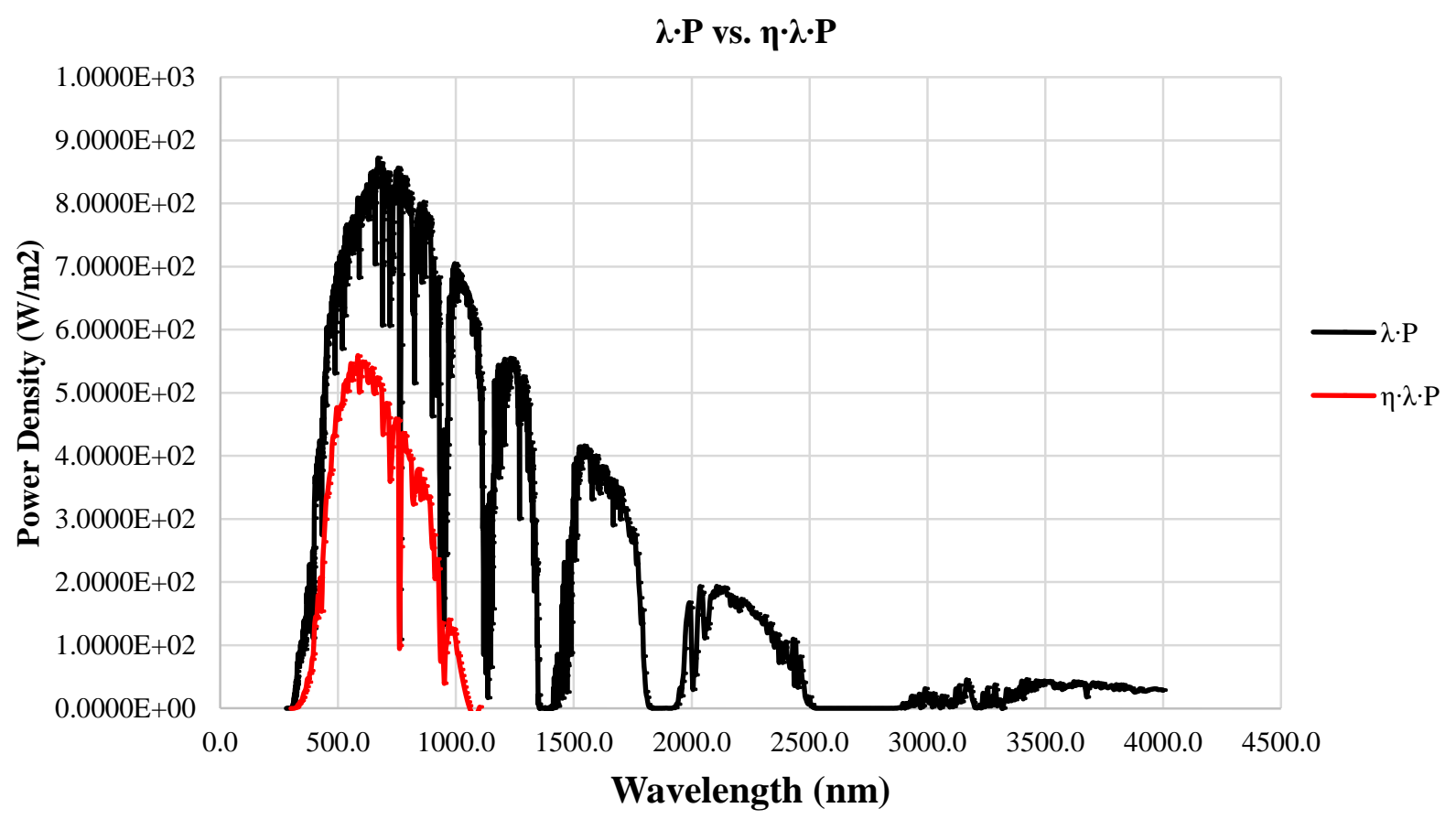

Figure 3: Graph providing a visual representation of equation (6) in which the power density of the integrals in the numerator and denominator of equation (1) are plotted next to each other.

Looking at Figure 3, we can see that the energy produced by the solar cell, or the numerator of equation (1), is only a fraction of the total energy that would be produced if all of the sun's energy was absorbed, or the denominator in equation (1). This is because for any nonnegative function, the integral can be seen as the area under the curve of the function. Hence, the area under the function " $\eta \cdot \lambda \cdot P$ " is clearly a fraction of the area under the function " $\lambda \cdot P$ " and it also seems to agree with the result in equation (6) which stated that the energy produced by the solar cell is $28.898 \%$ of the total energy that could have been captured from the sun.

\section{DISCUSSION}

The objective of this project was to find the electrical efficiency of a specific solar cell. This objective was successfully accomplished and the electrical efficiency was calculated to be $28.9 \%$. 
This result is not very surprising as efficiencies for solar cells generally fall into the range of $15 \%-40 \%$. This electrical efficiency of $28.9 \%$ is on the top end of the spectrum and is thus quite efficient in comparison to the rest of today's solar cells. Calculations of electrical efficiencies for solar cells are very important because they allow energy users to be aware of how efficient their cells are and thus how much money they could potentially save on their electric bill, or something else of the sort. Also, since creating cheaper solar cells is of great interest right now, the electrical efficiencies of new solar cells will always have to be calculated in order to evaluate cost and viability.

\section{CONCLUSIONS AND RECOMMENDATIONS}

Finding sources of renewable energy is a very important point of interest in the world currently. In the past 100 years we have seen an increase in atmospheric carbon dioxide of about $50 \mathrm{ppm}$ (Honsberg and Bowden). At this rate if we don't take steps to reduce our atmospheric pollution we will end up with highly increased temperatures which could result in changes in wind patterns, rainfall, and even flooding due to melting of ice and snow around the world. One very obvious source of energy is from the sun, namely through the use of solar cells. This project focused on determining the electrical efficiency of a recently developed $\mathrm{CuInGaSe} 2$ solar cell. It is very important that future scientists and engineers work to create solar cells with greater electrical efficiencies in order to make solar energy more affordable. When the day comes that the use of solar energy is cheaper than the use of fossil fuels, there will be no reason to continue polluting our planet and leaving future generations with problems they didn't create.

Calculating the electrical efficiency of this solar cell involved the use of trapezoidal Riemann sums on two spreadsheets of data. It is a somewhat time-consuming calculation but it 
can be seen as an accurate approximation if the intervals of summation are sufficiently small. In this project intervals of $5 \mathrm{~nm}$ were used which resulted in a sum of 744 trapezoids for the integral in the denominator of equation (1) and a sum of 160 trapezoids for the integral in the numerator of equation (1). These quantities of summation are sufficiently large for a problem such as the one presented in this project since the approximation would not be off from the actual calculation by more than $1 \%$.

If someone does this same project, and improvement includes using even smaller intervals for the Riemann sums, or even using Simpson's rule for approximation to obtain a slightly more accurate approximation. Aside from that, future projects could be done to find the electrical efficiencies of any other newly developed solar cell.

\section{NOMENCLATURE}

\begin{tabular}{clc}
\hline Symbol & \multicolumn{1}{c}{ Description } & \multicolumn{1}{c}{ Value } \\
\hline $\mathrm{P}$ & $\begin{array}{l}\text { Spectral irradiance; also known as the power } \\
\text { density as a function of wavelength }\end{array}$ & $\begin{array}{c}\text { Watts per meter squared } \\
\text { times wavelength in } \mathrm{nm} \\
\left(\mathrm{W} / \mathrm{m}^{2} \cdot \mathrm{nm}\right)\end{array}$ \\
$\eta$ & $\begin{array}{l}\text { Quantum efficiency; fraction of incident photons } \\
\text { converted to electrons by a solar cell }\end{array}$ & No units \\
$\lambda$ & Wavelength & Nanometers $(\mathrm{nm})$ \\
\hline
\end{tabular}

\section{REFERENCES}

Bowden, Christiana and Stuart. PVEducation. 3 April 2015. 3 April 2015.

Campbell, Scott. Interview. Johnnie Cairns. 2015. 
Honsberg, Christiana and Stuart Bowden. PVEducation. 3 April 2015. <http://pveducation.org/>. Stewart, James. Essential Calculus: Early Transcendentals. Cengage Learning, 2012. Print.

\section{APPENDICES}

Table 2: Excerpt from given spectral irradiance data as well as compartmentalized computation of the integral in equation (4).

\begin{tabular}{|c|c|c|c|}
\hline \multicolumn{2}{|c|}{$\begin{array}{c}\text { Yearly average solar } \\
\text { irradiance at middle latitudes }\end{array}$} & \multirow[b]{2}{*}{$\lambda * \mathrm{P}$} & \multirow{2}{*}{$\begin{array}{l}\text { Integration of Equation (4) } \\
\qquad \int \lambda * \operatorname{Pd} \lambda \text { FROM:1705 } \lambda-3995 \lambda\end{array}$} \\
\hline $\begin{array}{l}\text { Wavelength } \\
\qquad(\mathrm{nm})\end{array}$ & $\begin{array}{l}\text { Spectral Irradiance } \\
\qquad \mathrm{W}^{*} \mathrm{~m}^{-2} * \mathrm{~nm}^{-1}\end{array}$ & & \\
\hline 280.0 & $2.5361 \mathrm{E}-26$ & $7.1011 \mathrm{E}-24$ & $1.2131 \mathrm{E}+05$ \\
\hline 280.5 & 1.0917E-24 & $3.0622 \mathrm{E}-22$ & + \\
\hline 281.0 & $6.1253 \mathrm{E}-24$ & $1.7212 \mathrm{E}-21$ & 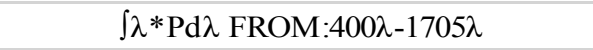 \\
\hline 281.5 & $2.7479 \mathrm{E}-22$ & 7.7353E-20 & 660054.3976 \\
\hline 282.0 & $2.8346 \mathrm{E}-21$ & $7.9936 \mathrm{E}-19$ & + \\
\hline 282.5 & $1.3271 \mathrm{E}-20$ & $3.7491 \mathrm{E}-18$ & $\int \lambda * \operatorname{Pd} \lambda$ FROM:3995 $\lambda-4000 \lambda$ \\
\hline 283.0 & $6.7646 \mathrm{E}-20$ & $1.9144 \mathrm{E}-17$ & $7.1199 \mathrm{E}+01$ \\
\hline 283.5 & $1.4614 \mathrm{E}-19$ & $4.1431 \mathrm{E}-17$ & + \\
\hline 284.0 & 4.9838E-18 & $1.4154 \mathrm{E}-15$ & 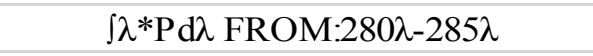 \\
\hline 284.5 & $2.1624 \mathrm{E}-17$ & $6.1520 \mathrm{E}-15$ & $1.7753 \mathrm{E}-23$ \\
\hline 285.0 & 8.9998E-17 & $2.5649 \mathrm{E}-14$ & + \\
\hline 285.5 & $6.4424 \mathrm{E}-16$ & $1.8393 \mathrm{E}-13$ & 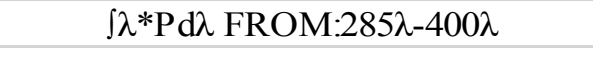 \\
\hline 286.0 & $2.3503 \mathrm{E}-15$ & $6.7219 \mathrm{E}-13$ & 11140.83821 \\
\hline 286.5 & $1.8458 \mathrm{E}-14$ & $5.2882 \mathrm{E}-12$ & $=$ \\
\hline 287.0 & 7.2547E-14 & $2.0821 \mathrm{E}-11$ & TOTALAPPROX. INTEGRAL OF $\int \mathbf{P}^{*} * \lambda d \lambda$ \\
\hline 287.5 & $3.6618 \mathrm{E}-13$ & $1.0528 \mathrm{E}-10$ & $\int \lambda * \operatorname{Pd} \lambda$ FROM:280 $\lambda-4000 \lambda$ \\
\hline 288.0 & $2.8061 \mathrm{E}-12$ & $8.0816 \mathrm{E}-10$ & 792580 \\
\hline 288.5 & $9.0651 \mathrm{E}-12$ & $2.6153 \mathrm{E}-09$ & \\
\hline 289.0 & $3.4978 \mathrm{E}-11$ & $1.0109 \mathrm{E}-08$ & \\
\hline 289.5 & $1.5368 \mathrm{E}-10$ & 4.4490E-08 & \\
\hline
\end{tabular}


Table 3: Excerpt from Excel spreadsheet containing interpolated quantum efficiency values, as well as a compartmentalized computation of the integral in equation (5).

\begin{tabular}{|c|c|c|c|c|}
\hline $\begin{array}{c}\text { Wavelength } \\
\lambda(\mathrm{nm})\end{array}$ & $\begin{array}{c}\text { Quantum } \\
\text { Efficiency, } \eta\end{array}$ & $\begin{array}{c}\lambda * \mathrm{P} \text { FROM } \\
300 \lambda-1100 \lambda\end{array}$ & $\lambda * \mathrm{P} * \eta$ & Integration of Equation (5) \\
\hline 300 & -0.021896173 & $1.3689 \mathrm{E}-01$ & $-2.9974 \mathrm{E}-03$ & $\int \eta \lambda P d \lambda$ FROM $300 \lambda-305 \lambda$ \\
\hline 305 & -0.012320397 & $2.7247 \mathrm{E}+00$ & $-3.3570 \mathrm{E}-02$ & -0.0074936 \\
\hline 310 & -0.000441889 & $8.6261 \mathrm{E}+00$ & $-3.8118 \mathrm{E}-03$ & + \\
\hline 315 & 0.013497316 & $2.3211 \mathrm{E}+01$ & 3.1329E-01 & $\int \eta \lambda P d \lambda$ FROM $305 \lambda-1095 \lambda$ \\
\hline 320 & 0.029267597 & $3.6086 \mathrm{E}+01$ & $1.0562 \mathrm{E}+00$ & 229030 \\
\hline 325 & 0.046651384 & $5.0388 \mathrm{E}+01$ & $2.3507 \mathrm{E}+00$ & + \\
\hline 330 & 0.065442814 & $8.6434 \mathrm{E}+01$ & $5.6565 \mathrm{E}+00$ & $\int \eta \lambda P d \lambda$ FROM 1095 $\lambda-1100 \lambda$ \\
\hline 335 & 0.085447378 & $8.8698 \mathrm{E}+01$ & $7.5790 \mathrm{E}+00$ & 5.0811 \\
\hline 340 & 0.10648158 & $1.0084 \mathrm{E}+02$ & $1.0738 \mathrm{E}+01$ & $=$ \\
\hline 345 & 0.128372599 & $9.6096 \mathrm{E}+01$ & $1.2336 \mathrm{E}+01$ & TOTAL APPROX. INTEGRAL OF $\int \eta \lambda P d \lambda$ \\
\hline 350 & 0.150957958 & $1.1520 \mathrm{E}+02$ & $1.7390 \mathrm{E}+01$ & 229040 \\
\hline 355 & 0.174085188 & $1.3895 \mathrm{E}+02$ & $2.4189 \mathrm{E}+01$ & \\
\hline 360 & 0.197611512 & $1.4126 \mathrm{E}+02$ & 2.7915E+01 & \\
\hline 365 & 0.22140352 & $1.5261 \mathrm{E}+02$ & $3.3788 \mathrm{E}+01$ & \\
\hline 370 & 0.245336854 & $1.9116 \mathrm{E}+02$ & 4.6900E+01 & \\
\hline 375 & 0.269295902 & $1.5408 \mathrm{E}+02$ & 4.1492E+01 & \\
\hline 380 & 0.293173485 & $1.8905 \mathrm{E}+02$ & $5.5426 \mathrm{E}+01$ & \\
\hline 385 & 0.316870563 & $1.8726 \mathrm{E}+02$ & $5.9336 \mathrm{E}+01$ & \\
\hline 390 & 0.340295931 & $2.2798 \mathrm{E}+02$ & 7.7581E+01 & \\
\hline 395 & 0.363365933 & $2.3738 \mathrm{E}+02$ & $8.6256 \mathrm{E}+01$ & \\
\hline 400 & 0.386004173 & $3.3596 \mathrm{E}+02$ & $1.2968 \mathrm{E}+02$ & \\
\hline 405 & 0.408141228 & $3.5579 \mathrm{E}+02$ & $1.4521 \mathrm{E}+02$ & \\
\hline
\end{tabular}

